\title{
ENGLISH INSURANCE LAW REFORMS: LESSONS FOR SOUTH AFRICA
}

\author{
Samantha Huneberg \\ BCom Law LLB LLM LLD \\ Lecturer, University of Johannesburg
}

\begin{abstract}
SUMMARY
Insurance law in the United Kingdom (UK) has recently undergone significant reforms. Until 2015, insurance law in the United Kingdom was still largely regulated by the Marine Insurance Act 1906. This meant that a statute created over a hundred years ago was still regulating insurance law. The need for the more recent reforms was evidently dire. The Law Commission undertook an investigation that highlighted the need for new insurance laws. The result was the enactment of the Insurance Act 2015. There are some significant changes in the new Act concerning fraudulent claims, breaches of good faith and the duty of disclosure. The new laws appear to be much more pro-policyholder than was the case in the previous regime. This article undertakes a detailed analysis of these reforms and also presents a comparison with South African laws. The ultimate question is whether South Africa can learn anything from the recent reforms to UK insurance law.
\end{abstract}

\section{1}

\section{INTRODUCTION}

Insurance law in the United Kingdom (UK) has recently undergone major reform. ${ }^{1}$ In August 2016, the most significant changes to UK insurance law in over a hundred years came into effect. ${ }^{2}$ The Insurance Act 2015 came into force bringing some major modifications to the UK insurance industry. The Act introduces key changes to the duty of disclosure in commercial insurance contracts as well as to the consequences for breaches of good faith, and to insurers' remedies for fraudulent claims. ${ }^{3}$ In order to place this statute into perspective and to appreciate how it has changed UK insurance law, a brief historic overview of the UK law is provided.

This article aims to evaluate the recent reforms in UK insurance law as well as to assess the impact that these reforms have had on the insurance industry. Firstly, it is necessary to consider the insurance laws applying in

\footnotetext{
Law Commission and the Scottish Law Commission "Insurance Contract Law: Business Disclosure; Warranties; Insurers' Remedies for Fraudulent Claims and Late Payment" (July 2014) https://www.scotlawcom.gov.uk/files/2814/0603/4624/Report_on Insurance Contract_Law.pdf (accessed 2018-04-15).

2 Soyer "Insurance Act 2015 Coming into Force: Overhauling Commercial Insurance Law in the UK" 2016 22(4) Journal of International Maritime Law 253-256.

3 Ibid.
} 
the UK before the 2015 Insurance Act was promulgated. ${ }^{4}$ Once the new laws have been evaluated, a comparison with South African law is undertaken. The ultimate question this article seeks to answer is whether South Africa can learn anything from the recent changes to UK insurance law.

\section{THE PREVIOUS LEGAL POSITION IN ENGLAND}

\section{The Marine Insurance Act 1906}

The most significant statute regulating insurance law in the UK was the Marine Insurance Act (MIA) $1906 .{ }^{5}$ Current UK insurance law stems from this very Act. The MIA codified the common-law principles that had been developed, largely in marine cases, in the eighteenth and nineteenth centuries. ${ }^{6}$ The most notable case from this period was Carter $v$ Boehm ${ }^{7}$ in that it established the duty of utmost good faith. ${ }^{8}$ Over the years, the MIA's provisions have been applied to marine and non-marine cases alike.

Notably, this Act saw the codification of the duty of utmost good faith, ${ }^{9}$ which is the cornerstone of UK insurance law. Section 17 of the MIA provided:

"A contract of marine insurance is a contract based upon the utmost good faith, and, if the utmost good faith be not observed by either party, the contract may be avoided by the other party."

Unlike the position in South Africa, insurance contracts in terms of UK law are still considered to be in utmost good faith. ${ }^{11}$ This concept of utmost good faith is of significance in UK insurance contracts. ${ }^{12} \mathrm{~A}$ contract of insurance is

4 Although the scope of the reforms is wide, this article only focuses on a few of the reforms, including those affecting the duty of fair presentation, good faith, fraudulent claims and late payment of claims. This article does not consider the reforms relating to warranties and contracting-out provisions.

5 Hertzell "Reforms to UK Insurance Law: Overview of Key Changes" (1 March 2016) https://uk.practicallaw.thomsonreuters.com/6-615-6445?transitionType=Default\&context Data $=($ sc. Default)\&firstPage $=$ true\&bhcp $=1$ (accessed 2018-04-15).

6 Konsta "Insurance Act 2015: Shaking up a Century of Insurance Law" (June 2016) https://www.clydeco.com/uploads/Files/Admin/CC010256_Insurance_Act_2015_26-07-16web.pdf (accessed 2018-04-15).

7 (1776) 3 Burr 1905 (Lord Mansfield).

8 The duty of utmost good faith is essentially a broad duty existing in uberrimae fidei contracts, of which insurance contracts are a type. Parties should refrain from engaging in conduct that is fraudulent, misrepresentative or causes undue influence.

9 Law Commission and the Scottish Law Commission https://www.scotlawcom.gov.uk/files/ 2814/0603/4624/Report_on_Insurance_Contract_Law.pdf (accessed 2018-04-15) par 127.

10 The duty of utmost good faith has undergone reform under the Insurance Act 2015 and is considered under heading 37 of this article.

11 See the South African judgment of Mutual and Federal Co. Ltd $v$ Oudtshoorn Municipality 1985 (1) SA 419 (A).

12 Take note that the enactment of the Insurance Act 2015 repealed parts of the Marine Insurance Act 1906. S 17 of the Act, which dealt with the duty of utmost good faith, was repealed in part by s 14 of the Insurance Act. S 14 repeals only that part of $s 17$ that says that a party may avoid the contract if the ground of utmost good faith has not been complied with. It would thus appear that the beginning part of $s 17$ (which states that contracts of marine insurance are based on the duty of utmost good faith) is still retained. 
said to be based on the principle of utmost good faith (uberrimae fidel). ${ }^{13}$ This principle was entrenched in section 17 of the MIA, which went on to state that, if the utmost good faith be not observed by either party, then the contract may be avoided by the other party. ${ }^{14}$

As far as the duty of disclosure is concerned, section 18 provided:

"The assured must disclose to the insurer, before the contract is concluded, every material circumstance which is known to the assured, and the assured is deemed to know every circumstance which, in the ordinary course of business, ought to be known by him. If the assured fails to make such disclosure, the insurer may avoid the contract."

The central element of section 18 was that it placed an onerous duty on the policyholder to disclose to the insurer "every material circumstance" that the policyholder "knows or ought to know" before concluding a contract. Under section 18(2), a material circumstance was defined as

"every circumstance which would influence the judgment of a prudent insurer in fixing the premium, or determining whether he will take the risk."

This section effectively required the policyholder to look into the mind of a hypothetical prudent insurer and guess what would influence it. ${ }^{17}$ Section 18 suggested that the insurer generally plays a relatively passive role; it did not need to ask questions or indicate what it wished to know. ${ }^{18}$ This led to

13 Birds, Lynch and Milnes MacGillivray on Insurance Law (2014) 453; Bell v Lever Bros Ltd [1932] A.C. 161 227; Yeo "Post-Contractual Good Faith-Change in Judicial Attitude?" 2003 66(3) Modern LR 425-440.

14 See s 17 of the Marine Insurance Act 1906; Birds et al MacGillivray on Insurance Law 453. Under s 17, the remedy for a breach of the duty of utmost good faith therefore, is avoidance of the contract $a b$ initio, which is a severe remedy that has retrospective effect and affords no right to damages.

15 Manifest Shipping Co Ltd v Uni-Polaris Insurance Co Ltd (The Star Sea) [2001] United Kingdom House of Lords 1, [2003] 1 AC 469 par 54; see also Law Commission and the Scottish Law Commission https://www.scotlawcom.gov.uk/files/2814/ 0603/4624/Report_on Insurance_Contract_Law.pdf par 3.7 and 3.8; see also Aswani "Non-Disclosure in Insurance Law: A More Principled Approach" 200664 Amicus Curiae 10.

16 In Pan Atlantic Insurance Co Ltd v Pine Top Insurance Co Ltd [1995] 1 Appeal Cases 501, the House of Lords confirmed that a material circumstance is one that would have an actual effect on the decision of the prudent insurer in assessing the risk.

17 See Lishman v Northern Maritime (1875) LR 10 Court of Common Pleas 179. S 18(3) deals with the exceptions to the duty to disclose and states: "Unless the insurer makes an enquiry, an insured need not disclose: (a) any circumstance which diminishes the risk; (b) any circumstance which is known or presumed to be known to the insurer. The insurer is presumed to know matters of common notoriety or knowledge, and matters which an insurer in the ordinary course of his business, as such, ought to know; (c) any circumstance as to which information is waived by the insurer; (d) any circumstance which it is superfluous to disclose by reason of any express or implied warranty."

18 See s 18 of the Marine Insurance Act 1906; see also Hertzell "Reforms to UK Insurance Law: Overview of Key Changes" https://uk.practicallaw.thomsonreuters.com/6-6156445 ?transitionType $=$ Default $\&$ contextData $=($ sc. Default $) \&$ firstPage $=$ true $\&$ comp $=$ pluk $\& b h c p=$ 1 (accessed 2019-02-05). 
policyholders burdening insurers with huge amounts of unnecessary information in an attempt to ensure that nothing was omitted. ${ }^{19}$

Misrepresentations were dealt with in section 20(1) of Act. The section stated:

"Every material representation made by the assured or his agent to the insurer during the negotiations for the contract, and before the contract is concluded, must be true. If it be untrue the insurer may avoid the contract."

The definition of a material representation in section 20(2) repeated the test for "material circumstances" in section 18(2).

An insurer, in the case of misrepresentations and non-disclosures, had only one remedy: avoidance of the contract. In other words, the contract was treated as if it had never been made, and all claims made under it were refused. ${ }^{22}$ Avoidance of the contract normally required restitution, ${ }^{23}$ except where the insured was guilty of fraud. ${ }^{24}$

It is evident that the past duty of disclosure in terms of the MIA was excessively wide. ${ }^{25}$ The policyholder was under a burden to disclose "every material circumstance" that might be relevant to an insurer, while the insurer was able to play a relatively passive role. This was an unfair practice that placed the already vulnerable policyholder in a detrimental position. ${ }^{26}$ These problems were compounded further by the fact that the only remedy for nondisclosure was avoidance of the contract.

\section{The move towards change}

It is surprising that UK insurance law was for so long based on a statute that is more than a hundred years old and that was originally only designed for marine insurance. ${ }^{27}$ Despite these hurdles, the insurance industry in the UK has thrived, mainly owing to a few statutory codifications and case law developments. ${ }^{28}$ However, with the many changes occurring since 1906, there was clearly a major need for reform in the insurance industry. In 2006, the Law Commission was asked to consider the existing insurance law

19 See s 18 of the Marine Insurance Act 1906; see also Aswani 200664 Amicus Curiae 11; see also Hertzell https://uk.practicallaw.thomsonreuters.com/6-615-6445?transitionType= Default\&contextData $=$ (sc. . Default $) \&$ firstPage $=$ true \&comp $=$ pluk\&bhcp $=1$.

20 See Economides v Commercial Union Assurance Co Plc [1998] Queen's Bench 587.

21 It must influence the judgement of a prudent insurer in fixing the premium or deciding whether to take the risk.

22 See s 17 of the Marine Insurance Act 1906.

23 The parties must be restored to the positions they were in prior to the contract being made.

24 See s 84(3)(a) of the 1906 Act which provides as follows: "Where the policy is void, or is avoided by the insurer as from the commencement of the risk, the premium is returnable, provided that there has been no fraud or illegality on the part of the assured ..."

25 Tyldesley "Consumer Insurance Law: Reform at Last?" 201081 Amicus Curiae 1.

26 Tyldesley "Insurance Law: Unfair, Unclear, Archaic and Inaccessible?" 200664 Amicus Curiae 1.

27 Konsta https://www.clydeco.com/uploads/Files/Admin/CC010256_Insurance_Act_2015_2607-16-web.pdf.

28 Ibid. 
regime in the UK to consider whether it was still fit for purpose in the modern insurance market. ${ }^{29}$

The Commission's conclusion was that the prevailing law was outdated and out of step with the realities of twenty-first century commercial practice. $^{30}$ The reviews culminated in the adoption of three new Acts of Parliament: firstly, the Third Parties (Rights against Insurers) Act 2010; ${ }^{31}$ secondly, the Consumer Insurance (Disclosure and Representation) Act $20123^{32}$ and lastly, the Insurance Act $2015 .^{33}$ As a result of the Law Commissions findings, the Insurance Bill 2014 was published and was first put before Parliament in July 2014. ${ }^{34}$ The Bill received Royal Assent on 12 February 2015 to become the Insurance Act 2015 and entered into force on 12 August 2016 to allow the market time to adjust its practices. ${ }^{35}$ Notably, the Insurance Act 2015 has amended certain key sections of the MIA, although the 1906 Act has not been repealed. ${ }^{36}$ This article focuses on how the new Insurance Act 2015 has changed the previous legal position under the MIA.

\section{$3 \quad$ THE INSURANCE ACT 2015}

\section{Introduction}

The newly enacted Insurance Act 2015 seeks to create a fairer balance between policyholders and insurers. ${ }^{37}$ The Act creates new duties for both insurer and policyholders ${ }^{38}$ and regulates the duty of disclosure, both before a contract comes into being and when a contract is amended. ${ }^{39}$ The Act also addresses warranties (including basis-of-contract clauses), fraudulent claims by a policyholder, breaches of good faith and lastly, some amendments to the Third Parties (Rights Against Insurers) Act 2010. ${ }^{40}$ The Act does not intend to be a full codification of insurance laws; alongside it, other laws on

29 Tyldesley 200664 Amicus Curiae 1-2; see also Konsta https:/www.clydeco.com/uploads/ Files/Admin/CC010256_Insurance_Act_2015_26-07-16-web.pdf.

30 See Law Commission and the Scottish Law Commission https://www.scotlawcom.Gov.uk/ files/2814/0603/4624/Report_on_Insurance_Contract_Law.pdf; Tyldesley 200664 Amicus Curiae 1.

31 Which came into force 1 August 2016.

32 Which came into force on 6 April 2013

33 Which came into force on 12 August 2016.

34 See Law Commission and the Scottish Law Commission https://www.scotlawcom.gov.uk/ files/2814/0603/4624/Report_on_Insurance_Contract_Law.pdf.

35 Ibid.

36 See Konsta https://www.clydeco.com/uploads/Files/Admin/CC010256_Insurance_Act 2015_26-07-16-web.pdf.

37 Merkin and Gurses "The Insurance Act 2015: Rebalancing the Interests of the Insurer and the Assured" 2015 78(6) Modern LR 1008.

38 Merkin and Gurses 2015 78(6) Modern LR 1008-1010.

39 Hertzell and Burgoyne "The Law Commissions and Insurance Contract Law Reform: An Update" 20132 Journal of International Maritime Law 105, 110-111.

40 Warranties are not discussed in this article. Take note that "basis of contract" clauses have been abolished by the 2015 Act. 
insurance, such as the 1906 MIA and the Third Parties Rights Against Insurers Act 2010, continue to apply. ${ }^{41}$

The Act applies to England, Wales, Scotland and Northern Ireland. ${ }^{42}$ The new law, rather than being a rigid code, sets out principles to be followed, with the aim of being sufficiently flexible to cater for entities ranging from the smallest business to major corporations.

The new duty of fair presentation and the new effect of a breach of the duty of good faith apply only in relation to contracts of insurance entered into on or after 12 August 2016 and to variations agreed on or after 12 August 2016 in respect of contracts agreed at any time. ${ }^{44}$ The new law on warranties, terms not relevant to the actual loss, and fraudulent claims applies only in relation to contracts of insurance entered into on or after 12 August 2016, and to variations of such contracts. ${ }^{45}$

An analysis of the sections that have undergone reform in terms of the Insurance Act 2015 are now considered.

\section{The duty of fair presentation}

Section 2 of the Act sets out the application and interpretation of the new duty of fair presentation. This duty applies to non-consumer contracts and the variation thereof. ${ }^{47}$

Section 3 defines what is meant by the duty of fair presentation. Before a contract of insurance is entered into, the policyholder must make a fair presentation of the risk to the insurer ${ }^{48} \mathrm{~A}$ fair presentation of the risk is described in subsection (3) as one that makes the disclosure required by subsection (4). ${ }^{49}$ In addition to this, the representation or the disclosure must be made in a manner that would be reasonably clear and accessible to a prudent insurer, and

41 See Soyer 2016 22(4) Journal of International Maritime Law 256.

42 Hertzell and Burgoyne 20132 Journal of International Maritime Law 116-123.

43 Hertzell and Burgoyne 20132 Journal of International Maritime Law 118-122; Soyer 2016 22(4) Journal of International Maritime Law 255; Merkin and Gurses 2015 78(6) Modern LR 1027. Before the introduction of the Insurance Act 2015, in South Africa there was little differentiation between insurance companies based on the size of the company. This is expected to change in the Twin Peaks dispensation.

44 Merkin and Gurses 2015 78(6) Modern LR 1028-1030.

45 Merkin and Gurses 2015 78(6) Modern LR 1020-1027; Hertzell and Burgoyne 20132 Journal of International Maritime Law 123.

46 Take note that warranties are not addressed hereunder, but that the Act has abolished all "basis of contract" clauses.

47 Ss (2) states: "this Part applies in relation to variations of non-consumer insurance contracts as it applies to contracts, but - (a) references to the risk are to be read as references to changes in the risk relevant to the proposed variation, and (b) references to the contract of insurance are to the variation." A non-consumer insurance contract "means a contract of insurance that is not a consumer insurance contract".

48 See ss (1).

49 Ss (4) provides: "The disclosure required is as follows, except as provided in subsection (5) - (a) disclosure of every material circumstance which the insured knows or ought to know, or (b) failing that, disclosure which gives the insurer sufficient information to put a prudent insurer on notice that it needs to make further enquiries for the purpose of revealing those material circumstances." 
"in which every material representation as to a matter of fact is substantially correct, and every material representation as to a matter of expectation or belief is made in good faith."

Section 4 sets out what constitutes knowledge of the policyholder and stipulates that a policyholder is an individual who knows only what is actually known to him/her or what is known to one or more individuals who are responsible for the policyholder's insurance.

\section{Subsection (3) goes on to provide that a policyholder}

"who is not an individual knows only what is known to one or more of the individuals who are -

(a) part of the insured's senior management, or

(b) responsible for the insured's insurance.".52

What is significant about this statute is that disclosure of knowledge under the MIA used to be a duty that was placed only on the prospective policyholder. The important shift that took place to a shared responsibility for disclosure between policyholders and insurers is evident from section 5, which describes what is meant by the knowledge of the insurer:

“(1) For the purposes of section 3(5)(b), an insurer knows something only if it is known to one or more of the individuals who participate on behalf of the insurer in the decision whether to take the risk, and if so on what terms (whether the individual does so as the insurer's emplovee or agent, as an employee of the insurer's agent or in any other capacity).

(2) For the purposes of section $3(5)(c)$, an insurer ought to know something only if -

(a) an emplovee or agent of the insurer knows it, and ought reasonably to have passed on the relevant information to an individual mentioned in subsection (1), or

(b) the relevant information is held by the insurer and is readily available to an individual mentioned in subsection (1).

(3) For the purposes of section 3(5)(d), an insurer is presumed to know -

(a) things which are common knowledge, and

50 See s $3(3)(b)-(c)$. S 3(5) goes on to provide: "In the absence of enquiry, subsection (4) does not require the insured to disclose a circumstance if - (a) it diminishes the risk, (b) the insurer knows it, (c) the insurer ought to know it, (d) the insurer is presumed to know it or (e) it is something as to which the insurer waives information."

51 See $\mathrm{s}$ 4(2).

52 The rest of the section goes on to state: "(4) An insured is not by virtue of subsection $(2)(b)$ or $(3)(b)$ taken to know confidential information known to an individual if - (a) the individual is, or is an employee of, the insured's agent; and (b) the information was acquired by the insured's agent (or by an employee of that agent) through a business relationship with a person who is not connected with the contract of insurance. (5) For the purposes of subsection (4) the persons connected with a contract of insurance are - (a) the insured and any other persons for whom cover is provided by the contract, and (b) if the contract reinsures risks covered by another contract, the persons who are (by virtue of this subsection) connected with that other contract. (6) Whether an individual or not, an insured ought to know what should reasonably have been revealed by a reasonable search of information available to the insured (whether the search is conducted by making enquiries or by any other means). (7) In subsection (6) "information" includes information held within the insured's organisation or by any other person (such as the insured's agent or a person for whom cover is provided by the contract of insurance)." See ss 8 for definitions. 
(b) things which an insurer offering insurance of the class in question to insureds in the field of activity in question would reasonably be expected to know in the ordinary course of business."

\section{Section 6 of the Act describes the concept of knowledge in general:}

“(1) For the purposes of sections 3 to 5, references to an individual's knowledae include not only actual knowledae, but also matters which the individual suspected, and of which the individual would have had knowledge but for deliberately refraining from confirming them or enquiring about them.

(2) Nothing in this Part affects the operation of any rule of law according to which knowledge of a fraud perpetrated by an individual ("F") either on the insured or on the insurer is not to be attributed to the insured or to the insurer (respectively), where -

(a) if the fraud is on the insured, $\mathrm{F}$ is any of the individuals mentioned in section $4(2)(b)$ or (3), or

(b) if the fraud is on the insurer, $\mathrm{F}$ is any of the individuals mentioned in section $5(1) . "$

Section 7 contains supplementary provisions relating to the duty of fair presentation $^{53}$ and section 8 sets out the remedies for breach. ${ }^{54}$

In summary, the potential policyholder is now under an obligation to disclose everything that is known to him or her, or which should be known to him or her, that will affect the insurer's decision whether to accept the risk, as well as all information regarding applicable insurance coverage to which it is important to draw the attention of the insurer. ${ }^{55}$ The policyholder, however,

53 "(1) A fair presentation need not be contained in only one document or oral presentation. (2) The term 'circumstance' includes any communication made to, or information received by, the insured. (3) A circumstance or representation is material if it would influence the judgement of a prudent insurer in determining whether to take the risk and, if so, on what terms. (4) Examples of things which may be material circumstances are - (a) special or unusual facts relating to the risk, (b) any particular concerns which led the insured to seek insurance cover for the risk, (c) anything which those concerned with the class of insurance and field of activity in question would generally understand as being something that should be dealt with in a fair presentation of risks of the type in question. (5) A material representation is substantially correct if a prudent insurer would not consider the difference between what is represented and what is actually correct to be material. (6) A representation may be withdrawn or corrected before the contract of insurance is entered into."

54 "(1) The insurer has a remedy against the insured for a breach of the duty of fair presentation only if the insurer shows that, but for the breach, the insurer - (a) would not have entered into the contract of insurance at all, or (b) would have done so only on different terms. (2) The remedies are set out in Schedule 1. (3) A breach for which the insurer has a remedy against the insured is referred to in this Act as a "qualifying breach". (4) A qualifying breach is either - (a) deliberate or reckless, or (b) neither deliberate nor reckless. (5) A qualifying breach is deliberate or reckless if the insured - (a) knew that it was in breach of the duty of fair presentation, or (b) did not care whether or not it was in breach of that duty. (6) It is for the insurer to show that a qualifying breach was deliberate or reckless."

55 S 3(4) (a)-(b) of the 2015 Act. S 4(6) provides that insured parties will be considered to have known, or ought to have known: matters that could be expected to be revealed by a reasonable search of information available to the insured party - for example, information held within an organisation or by a broker; anything known by a person responsible for their insurance - for example, a broker; insured organisations will also be deemed to have the knowledge of anyone who is a part of the organisation's senior management, or who is responsible for their insurance. See $s 4(7)$ in this regard. 
is not obliged to disclose matters already known to the insurer, and insurers are required to mention from the outset those matters that in their opinion they need for the purposes of accepting the insurance. ${ }^{56}$

\section{Evaluation of the duty of fair presentation}

By including a duty of fair presentation, the Act aims to encourage cooperation between the policyholder and the insurer at a pre-contractual stage. ${ }^{57}$ The duty requires that all presentations made should disclose all information in a reasonably clear and accessible manner. ${ }^{58}$ In addition, the potential policyholder must ensure that every material representation as to a matter of fact is substantially correct; and every material representation as to a matter of belief or expectation is made in good faith. ${ }^{5}$

Before the 2015 Insurance Act came into operation, potential policyholders were required to disclose every circumstance that they knew, or ought to have known, would influence an insurer in setting a premium or deciding whether to underwrite the risk. ${ }^{60}$ This generally required potential policyholders to predict, without much guidance from the insurer, what factors a hypothetical insurer would be influenced by ${ }^{61}$ This burden was somewhat cumbersome to the potential policyholder. The new Act ${ }^{62}$ has created a new "duty of fair presentation" aimed at encouraging more active, rather than passive, engagement by insurers, and has also clarified and specified known, or presumed-to-be-known, matters. ${ }^{63}$ Pre-disclosure

56 S 3(5) of the 2015 Act. S 5(2) states that "[i]nsurers will be considered to have known, or ought to have known: matters known to individuals who participate on behalf of the insurer in deciding whether to take the risk and on what terms - for example, underwriting teams; knowledge held by the insurer and readily available to the person deciding whether to take the risk; matters known by an employee or agent of the insurer and which should reasonably have been passed on to the person deciding whether to take the risk. Brokers will no longer be subjected to the old disclosure duties that they were subjected to previously." See also Thomas "The Insurance Act 2015 - A New Duty of 'Fair Presentation", 2016 Company Secretary's Review 4-6.

57 Birds et al MacGillivray on Insurance Law 575; see also Thomas 2016 Company Secretary's Review 45-49.

58 "Data dumping" will not be permissible.

58 Birds et al MacGillivray on Insurance Law 575.

58 The same obligation extended to brokers acting on behalf the insured should "signpost" material information to bring it to the insurer's attention.

59 See s 3(4); Thomas 2016 Company Secretary's Review 40-45.

60 Birds et al MacGillivray on Insurance Law 575. Take note that the Consumer Insurance (Disclosures and Representations Act) 2012 did amend the duty of disclosure to an extent but this was extended by the inclusion of these provisions on fair presentation.

61 Birds et al MacGillivray on Insurance Law 575; see also Law Commission and the Scottish Law Commission https://www.scotlawcom.gov.uk/files/2814/0603/4624/Report_on_ Insurance_Contract_Law.pdf par 62.

62 Part 2

63 "The insured party before entering into a contract of insurance, will be required to disclose either: every matter which they know, or ought to know, that would influence the judgement of an insurer in deciding whether to insure the risk and on what terms (very similar to the current position); or sufficient information to put an insurer on notice that it needs to make further enquiries about potentially material circumstances." See Birds et al MacGillivray on Insurance Law 575. 
analysis and filtering of relevant information is needed to ensure that disclosure is made in a reasonably clear and accessible manner. ${ }^{64}$

As already indicated, insurers are no longer able to rely on a passive approach to disclosure. ${ }^{65}$ More active engagement is encouraged. ${ }^{6}$

Section 8 of the new Act deals with remedies for the insurer in case of breach of contract. This section stipulates that if the potential policyholder is in breach of the duty of fair presentation, either deliberately or recklessly, then the insurer can avoid the policy and keep all premiums paid. ${ }^{67}$ In the case where a policyholder's breach is not deliberate or reckless, the insurer can avoid the policy and return all premiums paid provided that the insurer can prove that it would not have entered into the policy at all. If the insurer would have entered into the policy, but on different terms, the policy will be treated as if it included those terms. Lastly, if the insurer would have entered into the contract, but would have charged a higher premium, the insurer may reduce proportionately the amount to be paid on a claim to reflect that premium adjustment.

Previously, an insurer was able to refuse all claims under an insurance contract if the pre-contractual disclosure duty was breached, even if a broker committed the breach. ${ }^{69}$ The 2015 Act has now introduced a range of proportionate remedies applied according to the type of breach committed. ${ }^{70}$ It is important to note that these proportionate remedies are much fairer to the potential policyholder as the insurer can no longer avoid the contract in its entirety. This is in line with the balance of rights aimed at by the new Act. The practical implications of section 8 are important. To bring an action for relief for non-disclosure, insurers now need to prove that they would have acted differently if the breach had not occurred.

\section{Fraudulent claims}

The sections below dealing with fraudulent claims relate directly to fraud and provide much-needed clarity on how insurers should now deal with these types of claim.

64 Disclosure must be made in a reasonably clear and accessible manner, material representations of fact must be "substantially correct" and material representations of expectation or belief must be made in "good faith". The previous regime of "data dumping" has thus been addressed.

65 Birds et al MacGillivray on Insurance Law 575; see also Law Commission and the Scottish Law Commission https://www.scotlawcom.gov.uk/files/2814/ 0603/4624/Report_on_ Insurance Contract Law.pdf par 6 2; Thomas 2016 Company Secretary's Review 48-49. See Thomas 2016 Company Secretary's Review 47-49.

7 See 8 of the Insurance Act 2015.

68 Ibid.

69 Birds et al MacGillivray on Insurance Law 588-589; see also Law Commission and the Scottish Law Commission https://www.scotlawcom.gov.uk/files/2814/ 0603/4624/Report_on Insurance_Contract_Law.pdf par 1137.

70 Birds et al MacGillivray on Insurance Law 588-589.

71 Birds et al MacGillivray on Insurance Law 589; see also Law Commission and the Scottish Law Commission https://www.scotlawcom.gov.uk/files/2814/ 0603/4624/Report_on_ Insurance_Contract_Law.pdf par 11 44-11 46. 
Part 4 of the Act deals directly with fraudulent claims by an insured party. Section 12 of the Act deals with the remedies for fraudulent claims and states:

“(1) If the insured makes a fraudulent claim under a contract of insurance -

(a) the insurer is not liable to pay the claim,

(b) the insurer mav recover from the insured any sums paid by the insurer to the insured in respect of the claim, and

(c) in addition, the insurer may by notice to the insured treat the contract as having been terminated with effect from the time of the fraudulent act.

(2) If the insurer does treat the contract as having been terminated -

(a) it mav refuse all liability to the insured under the contract in respect of a relevant event occurring after the time of the fraudulent act, and

(b) it need not return any of the premiums paid under the contract.

(3) Treating a contract as having been terminated under this section does not affect the rights and obligations of the parties to the contract with respect to a relevant event occurring before the time of the fraudulent act.

(4) In subsections (2)(a) and (3), 'relevant event' refers to whatever qives rise to the insurer's liability under the contract (and includes, for example, the occurrence of a loss, the making of a claim, or the notification of a potential claim, depending on how the contract is written)."

Section 13 sets out the remedies for fraudulent claims in terms of group insurance. $^{72}$

\section{Evaluation of the fraudulent claims provisions}

Previously, in the event of fraud by a policyholder, the policyholder would forfeit the whole claim and insurers could also avoid the whole contract. ${ }^{73}$

Part 4 of the 2015 Act now sets out a clear statement of an insurer's remedies in the event of fraudulent claims brought by policyholders. The Act states that insurers will not be liable to pay a fraudulent claim, they may also recover any sums paid to the policyholder in respect of the fraudulent claim,

72 S 13 provides: "(1) This section applies where - (a) a contract of insurance is entered into with an insurer by a person ('A'), (b) the contract provides cover for one or more other persons who are not parties to the contract ('the Cs'), whether or not it also provides cover of any kind for A or another insured party, and (c) a fraudulent claim is made under the contract by or on behalf of one of the Cs ('CF'). (2) Section 12 applies in relation to the claim as if the cover provided for CF were provided under an individual insurance contract between the insurer and CF as the insured; and, accordingly - (a) the insurer's rights under section 12 are exercisable only in relation to the cover provided for CF, and (b) the exercise of any of those rights does not affect the cover provided under the contract for anyone else. (3) In its application by virtue of subsection (2), section 12 is subject to the following particular modifications - (a) the first reference to 'the insured' in subsection (1)(b) of that section, in respect of any particular sum paid by the insurer, is to whichever of $A$ and $C F$ the insurer paid the sum to; but if a sum was paid to $A$ and passed on by $A$ to $C F$, the reference is to CF, (b) the second reference to 'the insured' in subsection (1)(b) is to A or CF, (c) the reference to 'the insured' in subsection $(1)(c)$ is to both CF and $A$, (d) the reference in subsection $(2)(b)$ to the premiums paid under the contract is to premiums paid in respect of the cover for CF."

73 McGee The Modern Law of Insurance (2011) 274-275. 
and may also, by notice to the policyholder, treat the insurance policy as terminated with effect from the date of the fraudulent act and retain all premiums paid. Therefore, any previous valid claims remain unaffected. ${ }^{74}$

The 2015 Act introduces a default statutory regime for fraudulent claims submitted by policyholders. Insurers will remain liable for claims arising before the fraudulent act is committed but now have the option of terminating the contract as from the date of the fraudulent act without returning the premium. ${ }^{75}$ For group insurance, the Act provides that fraudulent claims made by one beneficiary under the policy will not affect the cover provided under the contract to other parties.

\section{Late payment of insurance claims}

The Act has also introduced provisions on late payments of insurance claims. Under the previous laws, insurers had no legal obligation to pay valid claims within a reasonable time. ${ }^{77}$ The Enterprise Act 2016 has now amended the Insurance Act 2015 from 4 May 2017 to enable policyholders to claim damages suffered as a result of insurers' unjustified "late" payment of a claim. ${ }^{78}$ A policyholder can sue an insurer to recover a valid claim. Provisions relating to the late payment of insurance claims were incorporated into the Enterprise Act 2016, which inserted additional provisions into the Insurance Act 2015 , by introducing an implied term into every insurance contract that insurers must pay claims within a "reasonable time".

The concept of "reasonable time" depends on the specific circumstances of each case but the Act provides a non-exhaustive list of factors that include: (i) the type of insurance; (ii) the size and complexity of the claim; (iii) compliance with any relevant statutory or regulatory rules or guidance; and (iv) factors outside the insurer's control. ${ }^{80}$ Section $13 \mathrm{~A}$ deals with the implied term about payment of claims and provides:

"(1) It is an implied term of every contract of insurance that if the insured makes a claim under the contract, the insurer must pay any sums due in respect of the claim within a reasonable time.

(2) A reasonable time includes a reasonable time to investigate and assess the claim.

(3) What is reasonable will depend on all the relevant circumstances, but the followina are examples of things which may need to be taken into account -

(a) the type of insurance,

(b) the size and complexity of the claim,

See $\mathrm{s} 12$ of the Insurance Act 2015.

Ibid.

See $s 13$ of the Insurance Act 2015

See Arnold-Dwyer "Insurance Law Reform by Degrees: Late Payment and Insurable Interest" 2017 80(3) Modern LR 489-491.

78 See President of India v Lips Maritime Corp (The Lips) [1988] Appeal Cases 395 (House of Lords).

79 See Sprung $v$ Royal Insurance Co (UK) Ltd [1997] CLC 70 (CoA).

80 See S $13 \mathrm{~A}(3)$ of the Insurance Act 2015. See also Photo Production Ltd $v$ Securicor Transport Ltd [1980] 1 Lloyd's Rep 139 (House of Lords). 
(c) compliance with any relevant statutory or regulatory rules or guidance,

(d) factors outside the insurer's control.

(4) If the insurer shows that there were reasonable grounds for disputing the claim (whether as to the amount of any sum payable, or as to whether anything at all is payable) -

(a) the insurer does not breach the term implied by subsection (1) merely by failing to pay the claim (or the affected part of it) while the dispute is continuing, but

(b) the conduct of the insurer in handlina the claim mav be a relevant factor in deciding whether that term was breached and, if so, when.

(5) Remedies (for example, damages) available for breach of the term implied by subsection (1) are in addition to and distinct from -

(a) any right to enforce payment of the sums due, and

(b) any right to interest on those sums (whether under the contract, under another enactment, at the court's discretion or otherwise)."

\section{Good faith}

Previously, in terms of section 17 of the MIA, contracts of insurance were based on utmost good faith and if the policyholder breached this duty, then the insurer could avoid the contract in its entirety. ${ }^{81}$ In terms of section 14 of the 2015 Act, no party may now avoid the contract based on the ground that the duty of utmost good faith has not been complied with. ${ }^{82}$

Section 14 deals with good faith and states:

"(1) Any rule of law permitting a party to a contract of insurance to avoid the contract on the ground that the utmost good faith has not been observed by the other party is abolished.

(2) Any rule of law to the effect that a contract of insurance is a contract based on the utmost good faith is modified to the extent required by the provisions of this Act and the Consumer Insurance (Disclosure and Representations) Act 2012.

(3) Accordingly -

(a) in section 17 of the Marine Insurance Act 1906 (marine insurance contracts are contracts of the utmost good faith), the words from ", and" to the end are omitted, and

(b) the application of that section (as so amended) is subject to the provisions of this Act and the Consumer Insurance (Disclosure and Representations) Act 2012.

(4) In section 2 of the Consumer Insurance (Disclosure and Representations) Act 2012 (disclosure and representations before contract or variation), subsection (5) is omitted."

It is thus clear that section 14 does not repeal section 17 of the MIA in its entirety. Rather, section 14 repeals only the part of section 17 that says that the insurer may avoid the contract in its entirety if the duty of utmost good faith has not been complied with. This means that contracts of insurance are still based on utmost good faith and this concept still plays a significant role in a contract of insurance. It can also be said that this duty goes hand in

81 See the South African position on good faith, which stemmed from the decision in Mutual and Federal Co. Ltd v Oudtshoorn Municipality supra.

82 See s 14(1) of the Insurance Act 2015. 
hand with the duty of fair presentation, as that section requires policyholders not to make any misrepresentations to the insurer, which can be said to be a duty to act in good faith. If it is required that a policyholder should not make any misrepresentations to an insurer, then this essentially imposes a duty to act in good faith on the policyholder.

\section{Evaluation of the good faith provisions}

In terms of the provisions dealing with good faith, the 2015 Act provides a default regime. ${ }^{8}$

Before the enactment of the 2015 Act, either party could avoid an insurance contract if the other failed to act in accordance with "utmost good faith" ${ }^{84}$ Part 5 of the Act has now removed avoidance of contract as a remedy for breach of this duty, and has abolished the parts of legislation prescribing this as a remedy. ${ }^{85}$ Insurance contracts are still based on utmost good faith, and clauses and obligations will be interpreted in a way that favours compliance with this duty. ${ }^{86}$ In a sense, the Act aligns the English position with the South African position.

\section{COMPARISON WITH SOUTH AFRICA}

The recent reforms in English insurance law are significant because of their impact on policyholders. It is evident from the above analysis that the new laws are strongly aimed at policyholder protection. They seek to create a fairer balance between insurer and policyholder. This is in line with the strong policyholder protection statutes that the UK has adopted in recent years.

South African insurance law is still largely based on the common law ${ }^{88}$ and we have not seen any major reforms in our insurance law regime regarding the fundamental concepts on which the insurance is based. ${ }^{89}$ Therefore, concepts like good faith, disclosure and fraudulent claims are still based on the common law.

83 Birds et al MacGillivray on Insurance Law 591-593.

84 Birds et al MacGillivray on Insurance Law 591; see also the South African position on good faith, which stemmed from the decision in Mutual and Federal Co. Ltd $v$ Oudtshoorn Municipality supra.

85 See s 14 of the Insurance Act 2015; see Birds et al MacGillivray on Insurance Law 591.

86 See s 14 of the Insurance Act 2015; see also Axa General Insurance Ltd v Clara Gottlieb and Joseph Meyer Gottlieb [2005] EWCA Civ 112 English Court of Appeal.

87 For eg, the Consumer Rights Act 2015. South Africa has also seen a strong move towards consumer protection with the introduction of the Consumer Protection Act 68 of 2008 (although this Act does not apply to the insurance industry) as well as the recent introduction of "Fair Treatment of Policyholders" in the Policyholder Protection Rules 2017 published in terms of s 55 of the Short-term Insurance Act 53 of 1998. Which is Roman-Dutch law.

89 Examples include the duty of good faith, misrepresentations, disclosures and fraudulent conduct. The Policyholder Protection Rules are the most significant platform currently aimed at ensuring a fairer balance between the insurer and policyholder. 


\section{Duty of good faith and duty of disclosure}

In South Africa, contracts of insurance are contracts of good faith. South Africa does not recognise a duty of "utmost" good faith as in England. ${ }^{90}$ The duty of good faith and that of disclosure go hand in hand. Although the court in Mutual and Federal Co. Ltd v Oudtshoorn Municipality ${ }^{91}$ did not set out the content of the requirement of good faith as it pertains to insurance contracts, it held that there is a duty on the insured and the insurer to disclose to each other, prior to the conclusion of the contract of insurance, every fact relevant and material to the risk or to the assessment of the premium.

The duty of good faith with regard to insurance contracts relates in particular to the right of the insurer to receive precise and comprehensive information about facts that are relevant to its evaluation of the risk. ${ }^{93}$ Consequently, the duty requires the potential policyholder to refrain from furnishing false information and to volunteer such information as he or she may possess concerning material facts. ${ }^{94}$

The remedy for a breach of the duty of disclosure ${ }^{95}$ is avoidance of the policy at the instance of the insurer. ${ }^{96}$ If the insurer wishes to avoid the policy, it must do so within a reasonable time and, unless fraud is proven, must return the premium paid to the policyholder. ${ }^{97}$ The effect of such an action is to treat the insurance policy as if it had never come into existence. ${ }^{98}$ This is similar to the English position in terms of the MIA. It is suggested that South Africa should move away from avoidance as England has done in the 2015 Act.

The Short-term Insurance $\mathrm{Act}^{99}$ was amended in 2003 to clarify that a misrepresentation also includes a non-disclosure. ${ }^{100}$

90 See the South African judgment of Mutual and Federal Co. Ltd v Oudtshoorn Municipality supra.

91 Supra.

92 Reinecke, Van Niekerk and Nienaber South African Insurance Law (2013) 141.

93 Reinecke et al South African Insurance Law 142.

94 Reinecke et al South African Insurance Law 145-150; see also Pereira v Marine and Trade Insurance Co Ltd 19754 All SA 635 (A); 1975 (4) SA 745 (A) 755.

95 A breach of the duty of disclosure can take the form of not representing or describing the risk correctly which is referred to as misrepresentation and the holding back of known material information which is referred to as non-disclosure. Reinecke et al South African Insurance Law 145-150.

Reinecke et al South African Insurance Law 174.

Ibid.

98 Reinecke et al South African Insurance Law 175.

9953 of 1998.

$100 \mathrm{~S} 53$ of the Short-term Insurance Act 1998 was amended to include a definition of material misrepresentation and non-disclosure. The section provides that a statement is regarded as material if a reasonable, prudent person would consider that the particular information should have been correctly disclosed to the insurer, so that the insurer could properly assess the risk. Reinecke et al South African Insurance Law 166-167. Take note that this section will be repealed by the Insurance Act 18 of 2017 and misrepresentations will in future be regulated by the Policyholder Protection Rules. 
England introduced the change to the duty of disclosure through the inclusion of the duty of fair presentation in the 2015 Act. This duty now stipulates that insurers need to play a more active role in the pre-contractual stages of an insurance contract. South Africa is also moving towards introducing this concept to our law through the Policyholder Protection Rules (PPRs).

It is worth noting that the court in Mahadeo $v$ Dial Direct Insurance $L t d^{102}$ stated that insurers must ask the correct questions in order to determine the risk as they have a notion of the kind of information they require. The duty of fair presentation in English law clearly takes cognisance of this thorny issue. In South Africa, the General Code of Conduct (GCC) in terms of the Financial Advisory and Intermediary Services Act (FAIS Act) ${ }^{103}$ provides detailed rules on the pre-contractual duties of insurers when selling products. ${ }^{104}$ These stipulations are supplemented by rule 11.3.4 of the 2018 PPRs, which states:

"Information provided must enable a policyholder to understand the features of the policy and help the policyholder understand whether it meets the policyholder's requirements. In determining the level of information to be disclosed the insurer must consider -

(a) the factually established or reasonably assumed knowledge and experience of the policyholder or average targeted policyholder at whom the communication is targeted;

(b) the policy terms and conditions, including its main benefits, exclusions, limitations, conditions and its duration;

(c) the policy's overall complexity, including whether it is entered into together with other goods and services, and

(d) whether the same information has been provided to the policyholder previously and if so, when."

The fact that the Policyholder Protection Rules (PPRs) as well as case law are acknowledging that insurers must play a more active role in the precontractual stage is noteworthy. It is evident that there is a growing trend in both England and South Africa to compel insurers to take a more active role in determining the risk and to assist prospective policyholders to disclose the correct information. South Africa does not appear to be too far behind England in this regard but reform is still required.

\section{Fraudulent claims}

There is a significant difference in the approach followed by English law and South African law respectively when it comes to the effect of a fraudulent claim on the insurer's liability in the absence of an express provision in the insurance contract regulating the matter. ${ }^{105}$ In English insurance law, the effect at common law - that is, in the absence of a fraud-related clause - is

\footnotetext{
The PPRs are published in terms of s 55 of the Short-term Insurance Act 53 of 1998

[2008] JOL $21383(\mathrm{~W})$

37 of 2002.

104 See $\mathrm{s} 7$ of the FAIS GCC.

105 Reinecke et al South African Insurance Law 375-377.
} 
that the insured loses his or her claim in its entirety. ${ }^{106}$ The purpose of this rule is to deter all types of fraudulent claims. ${ }^{107}$

In South Africa, the common-law position on fraudulent claims only entitles an insurer to forfeit the entire claim and cancel the contract where the policyholder lodges a fabricated claim. ${ }^{108}$ With regard to exaggerated claims and valid claims accompanied by fraudulent means, the insurer may not forfeit the valid claim but is entitled to forfeit the fraudulent part of the claim. ${ }^{109}$ This is in line with Roman-Dutch law, which states that an insured can derive no benefit from his or her fraudulent conduct. ${ }^{110}$ The recent English-law amendments have finally provided certainty as to how an insurer may react to fraudulent claims. This is laudable. No longer need insurers rely on the courts to judge each case on its merits; instead, the Insurance Act has provided the remedies. It would be helpful for South Africa to have similar provisions in our statutes in order to create certainty on how insurers should react to fraudulent claims. ${ }^{111}$ It would no longer be left to a court to consider what the correct remedy for the insurer is. Instead, legislation would govern this specifically.

\section{Evaluation}

For the most part, it appears that South Africa is not too far from our UK counterpart in moving to a more equitable balance between insurer and policyholder but South Africa could do more. In terms of the duty of good faith and disclosure, South Africa should look at introducing more proportionate remedies for the insured based on the type of breach that has occurred. The fact that South Africa is recognising a more active role for insurers in the area of disclosure is laudable. We need to move away from the previous passive role of insurers, and somewhat onerous expectations of policyholders. The most significant lesson that South Africa can learn from the recent reforms in English law is perhaps with regard to fraudulent claims. South Africa needs clear and concise rules on how insurers should deal with fraudulent claims; the UK has shown the way through the introduction of sections 12 and 13 of the Insurance Act 2015.

106 McGee The Modern Law of Insurance 273.

107 Take note of the recent decision in England of Versloot Dredging BV v HDI Gerling Industrie Versichering AG [2016] UKSC 45, which changed the common-law position relating to valid claims accompanied by fraudulent devices. This type of fraudulent conduct no longer results in forfeiture of the claim.

108 Reinecke et al South African Insurance Law 377.

109 Reinecke et al South African Insurance Law 377. Take note that if the policy contains a forfeiture clause, then the insurer may forfeit any type of fraudulent claim lodged by a policyholder.

110 Reinecke et al South African Insurance Law 377.

111 It must also be remembered that when an insurance contract contains a forfeiture clause, then the insurer may forfeit the entire claim with regard to any type of fraudulent claim and cancel the contract. 


\section{$5 \quad$ CONCLUSION}

From the above analysis of UK insurance law, it is evident that there have been significant reforms featuring a strong element of policyholder protection within them and generally aimed at correcting the imbalances that existed between insurer and insured at common law.

South African insurance law is still largely based on our common law. Although not completely outdated, there is a need to bring some of our insurance laws more in line with policyholder protection rules, as has happened in the UK. South Africa would do well to look at the specific reforms introduced in the Insurance Act 2015 and consider reforming our laws accordingly. The key areas requiring reform in South African insurance law relate to the duty of disclosure and the area of fraudulent claims. It would be helpful to have legislation in place, similar to s 12 of the Insurance Act 2015, to deal effectively with an insurer's remedies in cases of fraudulent claims made by policyholders. Thus, South Africa can benefit and "learn" from the recent developments in insurance law in the UK. 